\title{
Stingless bees (Hymenoptera, Meliponini) feeding on stinkhorn spores (Fungi, Phallales): robbery or dispersal? ${ }^{1}$
}

\author{
Marcio L. Oliveira ${ }^{2,3}$ \\ Elder F. Morato ${ }^{2,3}$
}

\begin{abstract}
Records about stingless bee-fungi interaction are very rare. In Brazilian Amazonia, workers of Trigona crassipes (Fabricius, 1793) and Trigona fulviventris Guérin, 1835 visiting two stinkhorn species, Dictyophora sp. and Phallus sp., respectively, were observed. The workers licked the fungi gleba, a mucilaginous mass of spores covering the pileum. Neither gleba residue nor spores were found on the body surface of these bee workers. These observations indicate that these bee species include spores as a complement in their diet. On the other hand, they also suggest that these stingless bees can, at times, facilitate spore dispersal, in case intact spores are eliminated with the feces.

KEY WORDS. Stingless bee-fungi interaction, Dictyophora, Phallus, Phallales, robbery, spore dispersal, Trigona
\end{abstract}

Studies on stingless bee-fungi interaction are rare. This may be due to the fact that bees have been seen on very few fungi species, many of which have a very short life cycle. Many stinkhorns, for example, fruit in the middle of the night and last only until noon.

Near Coca, Ecuador, BURR et al. (1996) observed individuals of Trigona cf. branneri Cockerell, 1912 collecting the gleba of the stinkhorn Staheliomyces cinctus Ed. Fischer (Phallales) and depositing it on the corbiculae. Years before, however, ROUBIK (1989: 39) and ROUBIK (apud BURR et al. 1996) reported Trigona fulviventris Guérin, 1835, T. nigerrima Cresson, 1878 and T. amalthea (Olivier, 1789) collecting liquid exudates and possibly spores from Dictyophora sp. in Panama, but he did not offer further details.

The stinkhorns exhibit a structure called the gleba, which is an often mucilaginous mass of spores and associated structures (GUGLIOTA \& CAPELARI 1999: 94). According to PUTZKE \& PUTZKE (1998: 425) the gleba frequently has an unpleasant odor that attracts insects, mainly flies that act as dispersal agents when spores stick to their bodies. However, TuNO (1998) verified that when flies ingest the spores of two stinkhorns species, Dictyophora indusiata (Vent. \& Pers.) and D. duplicata Fisch. Some spores can pass intact through the alimentary canal, and they are eliminated together with the feces. He rarely found gleba stuck to the body surface of the flies.

1) Publication number 302 of the PDBFF (INPA/SI).

2) Departamento de Ciências da Natureza, Universidade Federal do Acre. 69915-900 Rio Branco, Acre, Brasil.

3) Projeto Dinâmica Biológica de Fragmentos Florestais (PDBFF-INPA/Smithsonian Institution). Caixa postal 478, Manaus, 69011-970 Amazonas, Brasil. 
In 1989 at approximately $06: 00 \mathrm{~h}$, the first author observed workers of Trigona crassipes (Fabricius, 1793) visiting an individual of Dictyophora sp. (Fig. la-b). The stinkhorn was beside a tree stump in reserve number 1501, belonging to the BDFFP/INPA-SI (Biological Dinamics of Forest Fragments Project/National Institute for Amazonia Research-Smithsonian Institution) near Manaus, Amazonas state, Brazil. The gleba was dark green, with a mucilaginous aspect, and it had no noticeable odor. The workers spent a long time on the pileum of the stinkhorn, licking the gleba, but they were never seen depositing it on the corbiculae. Recently, in November 1998, between 8:30 and 9:15 h, the second author observed several workers of Trigona fulviventris visiting an individual of Phallus sp. (Fig. 1c-d) beside a fallen trunk near Rio Branco, Acre state, Brazil. Voucher specimens were deposited in the bee collection of the University of São Paulo, at Ribeirão Preto, São Paulo state, Brazil (RPSP). The form and scent of the fungus was seemed that described above, and the bees behaved in a way similar to T. crassipes. A worker of Tetragona goettei Friese, 1900 was also observed on the pileum without collecting any substance, and the bee did not interact in any way with the T. fulviventris workers that were already present. Also in November 1998, between 6:30 and 7:30 h, near Xapuri, Acre state, Brazil, C. Salimon (pers. comm.) found several workers of Trigona sp. visiting an individual of Dictyophora sp., which was beside two other withered individuals. However, no note was taken concerning whether the bees were feeding on or collecting the gleba. In southeast Brazil, G. Azevedo (pers. comm.) observed workers of Partamona helleri (Friese, 1900) carrying pellets of unidentified spores on the corbiculae, enroute to the nest.

According to CAMARGO \& ROUBIK (1991: 32) Trigona crassipes, T. hypogea Silvestri, 1902 and T. necrophaga Camargo \& Roubik, 1991 have vestigial corbiculae, feed on fresh meat, lack pollen storage pots in the nest, and do not use pollen for brood feeding. For these authors, such characteristics constitute strong evidences that this group is obligatorily necrophagous. However, the observations presented here suggest that $T$. crassipes includes spores in his diet as a complement to necrophagy. This conclusion is reinforced by CAMARGO \& ROUBIK (1991: 28) because they observed $T$. crassipes nests with pots containing a yellow paste, composed of small amounts of pollen and many spores.

BURR et al. (1996) do not know the chemical composition of the gleba of $S$. cinctus, however, they suggest that it may serve as a sugar and protein source for $T$. cf. branneri. This is based on the fact that such composition is very common in other stinkhorns. One of us (EFM) tasted the gleba of Phallus sp., but it was bitter, an indication that the basic composition of the gleba may not be sugars, but rather amino-acids and proteins.

BURR et al. (1996) proposed two hypotheses to explain the T. cf. branneri and S. cinctus relationship: stingless bees of the genus Trigona, in addition to flies, could be dispersing the spores; or, these bees could play a role as parasites (?) in a mutualist relationship between stinkhorns and flies. However, they admit that any conclusion is still premature, because there is little knowledge about the necessary conditions for spore germination in Phallales. In a recent study from Japan, Drosophyllidae and Muscidae flies feeding on the gleba of Dictyophora indusiata and D. duplicata Fisch 

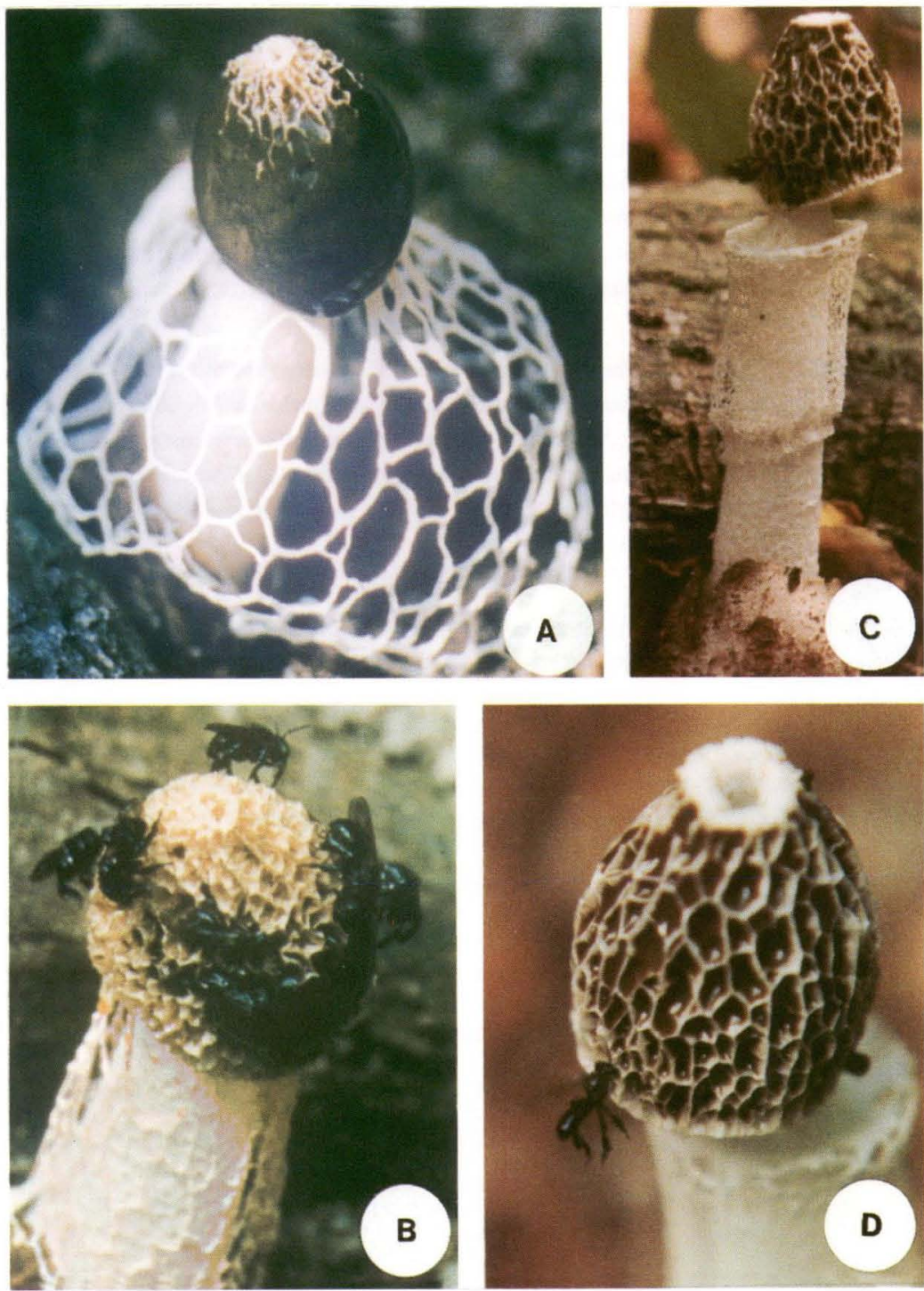

Fig. 1. (a) Dictyophora sp., general aspect of an individual found near Manaus, Amazonas, Brazil; (b) the same individual, some hours after, with Trigona crassipes workers licking the rest of gleba; (c) Phallus sp., general aspect of an individual found near Rio Branco, Acre, Brazil; (d) a Trigona fulviventris worker landing on the Phallus $\mathrm{sp}$. pileum.

eliminated intact spores in the feces with high germination rates (TuNO 1998). According to this author, the gleba of both Dictyophora species was rarely found stuck to the body surface of the flies, in spite of the gleba's adhesive character.

Neither gleba residue nor spores were found on the body surface of Trigona crassipes or T. fulviventris and these bees were not oberserved depositing gleba on the corbiculae. In spite of the fact that $T$. crassipes has vestigial corbiculae, workers 
have been observed carrying resin in this structure (ROUBIK 1982). Although stingless bees can digest spores, the observations presented here are a strong indication these bees can, at times, facilitate spore dispersal of some stinkhorn species, if intact spores are eliminated in their feces. In contrast, BURR's et al. (1996) observations suggest that bees may hinder spore dispersal, because $S$. cinctus gleba on the corbiculae of $T$. cf. branneri workers clearly indicates that this bee species uses the material to feed offspring or to construct and repair nests.

ACKNOWLEDGEMENTS. The authors thank João M.F. Camargo and Silvia R.M. Pedro for bee identification; Vera L. Bononi, Marina Capelari and Jair Putzke for fungus identification; Cleber I. Salimon and Gisele G. Azevedo for their communications; Maria Cristina Gaglianone and Gabriel A.R. Melo for valuable comments on the manuscript, J. Christopher Brown for language revision and PDBFF (INPA-SI) and SUFRAMA for support.

\section{REFERENCES}

Burr, B.; W. Barthlott \& C. Westerkamp. 1996. Staheliomyces (Phallales) visited by Trigona (Apidae): melittophily in spore dispersal of an Amazonian stinkhorn? Jour. Trop. Ecol. 12: 441-445.

CAMARGo, J.M.F. \& D.W. Roubik. 1991. Systematics and bionomics of the apoid obligate necrophages: the Trigona hypogea group (Hymenoptera: Apidae; Meliponinae). Biol. Jour. Linn. Soc. 44: 13-39.

Gugliota, A. DE M. \& M. CAPELARI. 1999. Taxonomia de Basidiomicetos, p. 69-102. In: V.L.R. BonONI

(Ed.). Zigomicetos, Basidiomicetos e Deuteromicetos. Noções básicas de taxonomia e aplicações biotecnológicas. São Paulo, Instituto de Botânica, Secretaria Estadual de Meio Ambiente, 184p.

Putzke, J. \& M.T.L. Putzke. 1998. Os reinos dos fungos. Santa Cruz do Sul, Edunisc, Vol. I, 606p.

RouBIK, D.W. 1982. Obligate necrophagy in the social bee. Science 217: 1059-1060.

1989. Ecology and Natural History of Tropical Bees. New York, Cambridge Univ. Press, $\mathrm{X}+514 \mathrm{p}$.

Tuno, N. 1998. Spore dispersal of Dictyophora fungi (Phallaceae) by flies. Ecol. Res. 13: 7-15.

Recebido em 02.IX.1999; aceito em 16.VIII.2000. 